\title{
SLC24A4 wt Allele
}

National Cancer Institute

\section{Source}

National Cancer Institute. SLC24A4 wt Allele. NCI Thesaurus. Code C162363.

Human SLC24A4 wild-type allele is located in the vicinity of $14 q 32.12$ and is approximately $179 \mathrm{~kb}$ in length. This allele, which encodes sodium/potassium/calcium exchanger 4 protein, plays a role in ion antiporter activity. Mutation of the gene is associated with hypomaturation type IIA5 amelogenesis imperfecta. 